\title{
Improvement of the Surface of the Combustion Chamber of a Piston using Selected Techniques of Production Organization
}

\author{
CZERWIŃSKA Karolina ${ }^{1, a}{ }^{*}$, DWORNICKA Renata ${ }^{2, c}$ and PACANA Andrzej ${ }^{1, c}$ \\ ${ }^{1}$ Rzeszow University of Technology, The Faculty of Mechanical Engineering and Aeronautics \\ Poland \\ ${ }^{2}$ Cracow University of Technology, Faculty of Mechanical Engineering, Kraków, Poland \\ ak.czerwinska@prz.edu.pl, brenata.dwornicka@mech.pk.edu.pl, capp@prz.edu.pl
}

\begin{abstract}
Keywords: Mechanical Engineering, Piston, Combustion Chamber, Eddy Current Testing
\end{abstract}

\begin{abstract}
The durability of aluminum pistons is determined by the resistance of the piston crown (combustion chamber) on pressure and temperature. There is a significant risk of fatigue cracking of the edges and the base of the chamber. Hence the need for continuous monitoring of the surface condition of the combustion chamber and prevention of possible incompatibilities. In the paper, the method of eddy currents in the quality control of the surface of combustion chamber of diesel engine pistons used in light vehicles was applied. The aim of the study was to determine, using traditional quality management tools, the sources of nonconformity of castings found in eddy current testing. Ultimately, the aim of the analysis was to reduce the number of non-compliant products or to eliminate them completely. In the analyzed batch of pistons, surface discontinuity in the form of cracks in the combustion chamber occurs most frequently. Based on the Pareto-Lorenza analysis, it can be concluded that this type of non-compliance generates the largest amount of losses (e. g. economic losses). The pistons in which the presented nonconformity has been identified will not be repaired. Therefore, in order to identify and eliminate the causes of non-compliance in the combustion chamber, the Ishikawa diagram in the $6 \mathrm{M}$ system was used to analyze the causes of non-compliance in the combustion chamber. On the basis of the in-depth analysis, it was concluded that insufficient feeding during the mold flooding was the key reason for the non-compliance.
\end{abstract}

\section{Introduction}

Internal combustion engines are the primary source of propulsion for vehicles. Despite intensive work on alternative sources of energy (fuel cells, electric motors), none of them is sufficiently developed to compete with combustion engines (referring to such aspects of its operation as traction characteristics, versatility, comfort of use taking into account the universality of fuel/energy, operating costs, service network, spare parts and finally the habits of vehicle users) $[1,2]$. An important role is played by ensuring the desired quality of engine components, which determines the need to eliminate products with sub-surface and surface incompatibilities. $[3,4,5$, 6]. The application of non-destructive testing in production quality control systems may be an effective method of detecting nonconformity in a finished product and its non-application to service. Tests qualified in the electromagnetic tests category are a type of non-destructive tests particularly suitable for diagnostics in the production process or during the product operation. [7, 8]. An example of such detection can be the eddy current method, during which all changes in the analyzed material, such as the change of structure, change of hardness and discontinuities 
affect the value of electromagnetic parameters, the value of eddy current intensity and induced magnetic field. Diagnostics of the values of electromagnetic field changes and amplitude as well as phase shift of voltage and intensity create the possibility to assess the condition of the examined product area. [9, 10, 11].

One of the main objectives of the production plants is to lead to a situation in which the production of defective products is significantly reduced. The large number of parameters and the complexity of the production process contribute to the fact that the determination of the causes and effects of a problem is not a simple task which requires systematization. $[12,13,14]$. For this reason, quality management tools are used that enable analysis, monitoring and immediate impact on the process throughout the product's production cycle. The Ishikawa diagram is one of the most popular and frequently used quality management tools. This diagram makes it possible to identify the most frequently occurring inconsistencies and to determine the reasons for their occurrence. [15, 16, 17].

The presented approach may be useful in other industrial and research activities that have problems with the occurrence of defects, e.g. biotechnology [18, 19], heat flows [20], hydraulic equipment of heavy duty machines [21], tools production [22] and improving their characteristics, in particular the surface layer [23-25]. It should be taken into account in related analysis e.g. process analysis [26, 27], image analysis [28], stereology analysis [29] and structure analysis [30].

\section{Experimental}

Purpose and scope of the research. The aim of the research was to diagnose the surface condition of the combustion chamber in a diesel piston in between operational and quality control using the eddy current method. It was also to identify the reasons for the occurrence of non-compliant castings where appropriate corrective and preventive action could ultimately contribute to reducing the number of non-compliant castings.

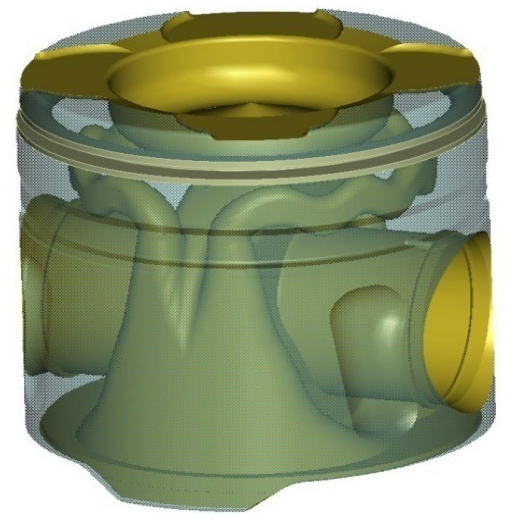

Fig. 1. Subject of the study - 3D model of a diesel piston.

The conducted research concerned the batch of products manufactured in the 1st quarter of 2019 in one of the production companies located in the southern part of Poland. The scope of casting control included verification of the surface of the casting combustion chamber, marking the place of non-compliance and precise determination of the type of identified non-compliance. The quality control also included verification of the correctness of the casting marking. Verification of the surface condition of the piston combustion chamber is carried out using visual 
inspection, dimensional inspection and eddy current method. Quality control was performed in accordance with the internal procedure of the company according to each production order.

Subject of the research. In order to assess the possibility of detecting internal inconsistencies in the material of the product, experimental tests were conducted. The subject of research was a piston designed for a diesel engine - a diesel engine used in passenger cars, manufactured by Toyota. The 3D model of the diesel piston is shown in Figure 1.

Pistons are cast from B2 alloy (designation functioning in the company), which is a eutectic aluminum and silicon alloy designed for the production of petrol and diesel pistons used in light vehicles. B2 alloy has no international or national equivalents.

Methodology of the research. Detection of discrepancies in the piston crown is carried out with the use of the Foerster Statograph Ds 6.440 system using appropriate handling systems. Built-in systems control the Kuka manipulator arm (equipped with Siemens Sinumerick D640/i software), which positions and rotates the tested product in relation to the diagnostic probe. Thanks to the rotating system, the probe rotates close to the surface of the piston combustion chamber. With each subsequent rotation of the probe, a new track is scanned. During the test, the results of the test are visualized. The device used is equipped with a system that controls the eddy current method according to EN 12084.

\section{Results and analysis}

The obtained results of tests carried out with the use of eddy current method in the combustion chamber of the diesel engine piston are presented in Figure 2a. The result of the tests showed the presence of an unacceptable material discontinuity in the combustion chamber of the piston. As a result, as part of the in-depth quality control and analysis, the identified discontinuity area was sampled and metallographed. The results of microscopic observations are presented in Figure $2 \mathrm{~b}$.

a)

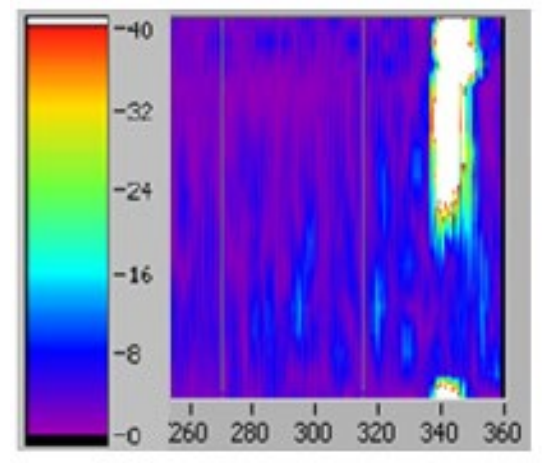

b)

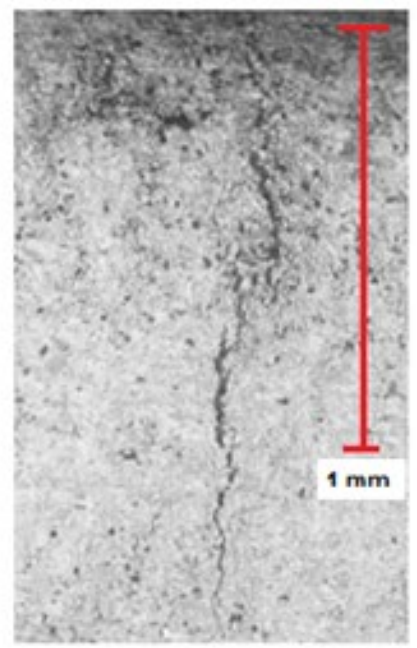

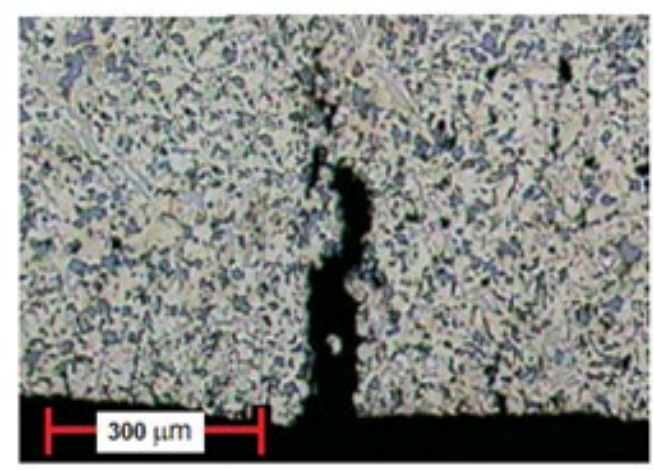

Fig. 2. a) The result of the eddy current testing of the piston crown with the indication of the detected unacceptable surface discontinuity; b) The result of metallographic surveys from the discontinuity area.

The presence of observed discontinuity - fracture of the chamber base results in qualitative disqualification of the piston. In the analyzed batch of products, the discontinuity of the combustion chamber surface in the form of cracks occurs most frequently. On the basis of the 
Pareto-Lorenza analysis, it can be concluded that this type of non-compliance contributes to the generation of a greatest number of losses (e. g. economic). Products in which the presented type of non-compliance has been identified are not subject to repair. Therefore, in order to identify and eliminate the causes of surface cracks in the combustion chamber, the Ishikawa diagram in the $6 \mathrm{M}$ system was used for analysis (Figure 3).

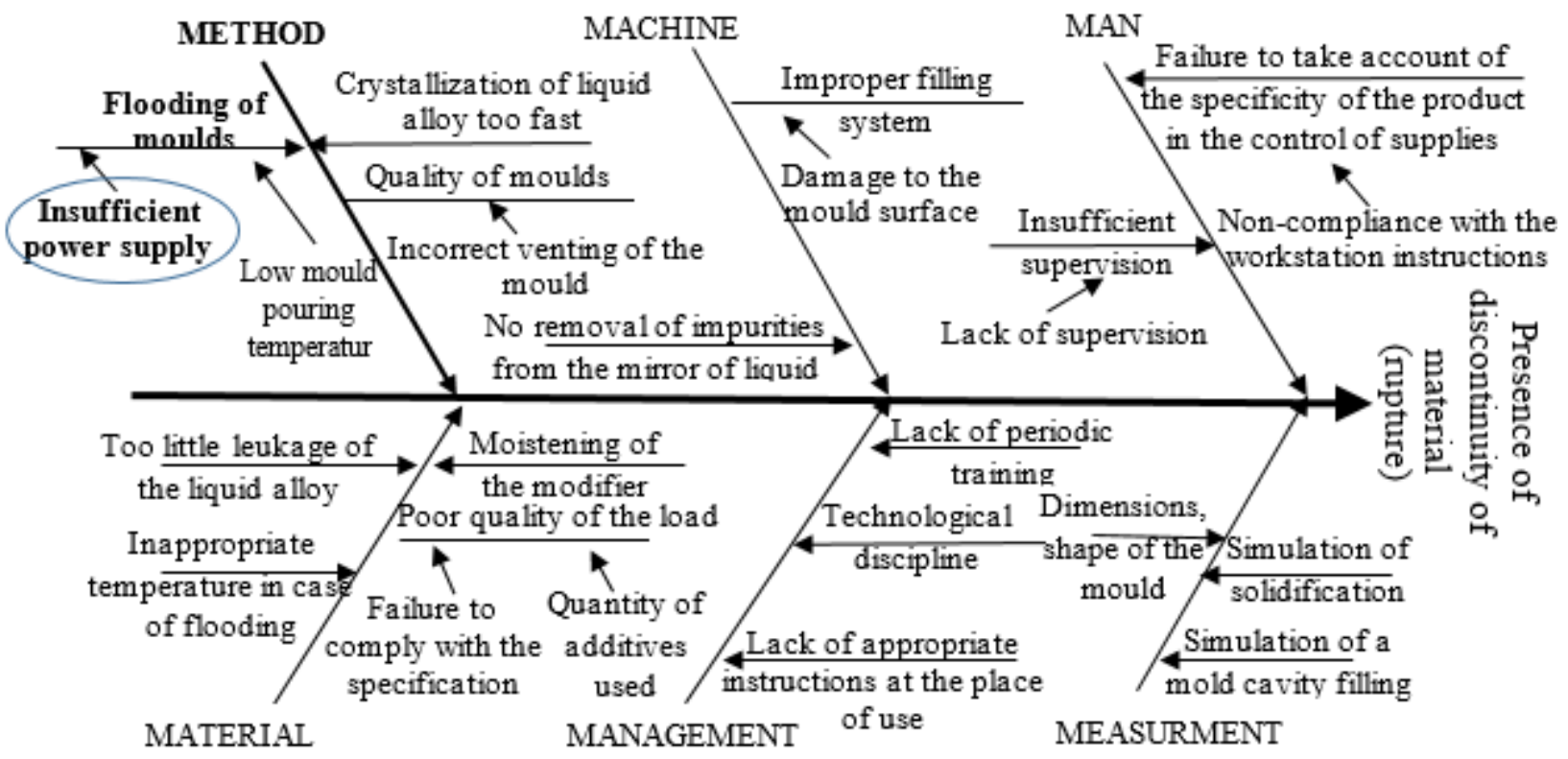

Fig. 3. Ishikawa diagram of the causes of cracks in the combustion chamber of pistons

Figure 3 presents factors influencing the formation of one of the most important pistons incompatibility for the enterprise- surface cracks in the combustion chamber. The most important factor influencing the occurrence of incompatibilities in the discussed series of products was distinguished in the scope of the method. In this group, the most important factor was insufficient power supply during the pouring of mould.

\section{Conclusion}

The paper presents an analysis with a diagnostic test of the combustion chamber of a diesel engine piston using the eddy current method. The aim of the test was to control the quality of the batch of products and to check the usefulness of the control and diagnostic test in the production process.

The non-destructive testing with the eddy current method located the discontinuity in the area of the combustion chamber - a casting defect (crack in the surface of the piston crown) and confirmed its presence by metallographic testing. The occurrence of discontinuities disqualifies the crown. Within the framework of the Pareto-Lorenz analysis, it was diagnosed that cracks in the combustion chamber are the most frequent inconsistencies in the tested batch of products. In order to prioritize the potential causes of non-compliance, a diagram of Ishikawa has been compiled. According to the diagram, the key reason for the non-compliance was insufficient power supply during the flooding of the mould.

The tool used in combination with the quality management method is largely complementary. The proposed combination may be a component of methods supporting quality management processes. 


\section{References}

[1] A. Olczyk, Analiza możliwości zwiększania mocy tłokowych silników spalinowych, Zeszyty Naukowe. Cieplne Maszyny Przepływowe - Turbomachinery, Politechnika Łódzka, 2012, nr 121.

[2] D. Malindzak et al., An effective model for the quality of logistics and improvement of environmental protection in a cement plant, Przemysl Chemiczny 96(9) (2019) 1958-1962.

[3] E.K. Vukelja, I. Duplančič, B. Lela, Continuous roll casting of aluminium alloys - casting parameters analysis, Metalurgija 49(2) (2010) 115-118.

[4] A. Pacana, A. Radon'-Cholewa, J. Pacana: The study of stickiness of packaging film by Shainin method, Przemysl Chemiczny 94(8) (2015) 1334-1336.

[5] M. Hajkowski, Ł. Bernat, J. Hajkowski, Mechanical Properties of Al-Si-Mg Alloy Castings as a Function of Structure Refinement and Porosity Fraction, Archives of Foundry Engineering 12(4) (2012) 57-64. https://doi.org/10.2478/v10266-012-0107-9

[6] A. Sanz, New coatings for continuous casting rolls, Surface and Coatings Technology 177-178 (2004) 1-11. https://doi.org/10.1016/j.surfcoat.2003.06.024

[7] A. Lewińska-Romicka, Badania nieniszczące. Podstawy defektoskopii. Warszawa, WNT, 2001.

[8] A. Pacana, L. Bednárová, I. Liberko et al., Effect of selected production factors of the stretch film on its extensibility, Przemysl Chemiczny 93(7) (2014) 1139-1140.

[9] N. Gil, G. Konovalov, A. Mayorov, Devices for non-destructive testing of adhesion quality of a ni-resist insert in diesel engine pistons, Previous Experience and Current Innovations in Non-Destructive Testing, Slovenia, 2001.

[10] J. Senkara, Współczesne stale karoseryjne dla Przemyslu motoryzacyjnego i wytyczne technologiczne ich zgrzewania, Przegląd Spawalnictwa 81 (11) (2009) 3-7.

[11] L. Tian, Y. Guo, J. Li, J. Wang, H. Duan, F. Xia, M. Liang, Elevated re-aging of a piston aluminium alloy and effect on the microstructure and mechanical properties. Materials Science and Engineering A 738 (2018) 375-379. https://doi.org/10.1016/j.msea.2018.09.078 [12] B. Slusarczyk, M. Szajt, Globalizacja jako element wzrostu konkurencyjności, Zeszyty Naukowe Politechniki Częstochowskiej. Zarządzanie 10 (2013) 98-110.

[13] A. Ebenzer, S. R. Daradasn, Total failure mode and effects analysis in tea industry: A theoretical treatise. Total Quality Management \& Business Excellence 22 (2011) 1353-1369. https://doi.org/10.1080/14783363.2011.625188

[14] R. Ulewicz, Quality Control System in Production of the Castings from Spheroid Cast Iron, Metalurgija 42(1) (2003) 61-63.

[15] A. Pacana, Praca zespołowa i liderzy, Rzeszów, Oficyna Wydawnicza Politechniki Rzeszowskiej, 2017.

[16] A. Gwiazda, Koncepcja ważonego wykresu Ishikawy, Problemy Jakości 4 (2005) 13-17.

[17] J. Sęp, R. Perłowski, A. Pacana, Techniki wspomagania zarządzania jakością. Reszów, Oficyna Wydawnicza Politechniki Rzeszowskiej, 2006.

[18] E. Skrzypczak-Pietraszek, A. Hensel, Polysaccharides from Melittis melissophyllum L. herb and callus. Pharmazie 55 (2000) 768-771. 
[19] E. Skrzypczak-Pietraszek, A. Urbanska, P. Zmudzki, J. Pietraszek, Elicitation with methyl jasmonate combined with cultivation in the Plantform ${ }^{\mathrm{TM}}$ temporary immersion bioreactor highly increases the accumulation of selected centellosides and phenolics in Centella asiatica (L.) Urban shoot culture. Engineering in Life Sciences. 19 (2019) 931-943.

https://doi.org/10.1002/elsc.201900051

[20] L. J. Orman, Boiling heat transfer on meshed surfaces of different aperture. AIP Conf. Proc. 1608 (2014) 169-172. https://doi.org/10.1063/1.4892728

[21] M. Domagala, H. Momeni, J. Domagala-Fabis, G. Filo, M. Krawczyk, J. Rajda, Simulation of particle erosion in a hydraulic valve. Materials Research Proceedings 5 (2018) 17-24. 10.21741/9781945291814-4

[22] M. Mazur, K. Mikova, Impact resistance of high strength steels. Materials TodayProceedings 3 (2016) 1060-1063. https://doi.org/10.1016/j.matpr.2016.03.048

[23] S. Wojciechowski, P. Twardowski, T. Chwalczuk, Surface Roughness Analysis after Machining of Direct Laser Deposited Tungsten Carbide, Met \& Props 2013, 14th Int. Conf. on Metrology and Properties of Eng. Surf., Journal of Physics Conference Series 483 (2014) art. 012018. https://doi.org/10.1088/1742-6596/483/1/012018

[24] D. Przestacki, M. Kuklinski, A. Bartkowska, Influence of laser heat treatment on microstructure and properties of surface layer of Waspaloy aimed for laser-assisted machining. Int. J. Adv. Manuf. Technol. 93 (2017) 3111-3123. https://doi.org/10.1007/s00170-017-0775-2 [25] P. Kieruj, M. Kuklinski, Tool life of diamond inserts after laser assisted turning of cemented carbides. MATEC Web of Conf. 121 (2017) art. UNSP 03011.

https://doi.org/10.1051/matecconf/201712103011

[26] J. Pietraszek, E. Skrzypczak-Pietraszek, The optimization of the technological process with the fuzzy regression. Adv. Mater. Res-Switz. 874 (2014) 151-155.

https://doi.org/10.4028/www.scientific.net/AMR.874.151

[27] J. Pietraszek, A. Gadek-Moszczak, T. Torunski, Modeling of Errors Counting System for PCB Soldered in the Wave Soldering Technology. Advanced Materials Research 874 (2014) 139-143. https://doi.org/10.4028/www.scientific.net/AMR.874.139

[28] A. Szczotok, D. Karpisz, Application of two non-commercial programmes to image processing and extraction of selected features occurring in material microstructure. METAL 2019: 28th Int. Conf. on Metallurgy and Materials, Ostrava, TANGER, 1721-1725. https://doi.org/10.37904/metal.2019.971

[29] L. Wojnar, A. Gadek-Moszczak, J. Pietraszek, On the role of histomorphometric (stereological) microstructure parameters in the prediction of vertebrae compression strength. Image Analysis and Stereology 38 (2019) 63-73. https://doi.org/10.5566/ias.2028

[30] J. Pietraszek, A. Gadek-Moszczak, The Smooth Bootstrap Approach to the Distribution of a Shape in the Ferritic Stainless Steel AISI 434L Powders. Solid State Phenomena 197 (2012) 162167. https://doi.org/10.4028/www.scientific.net/SSP.197.162 